\title{
Nutritional Status of Children in Three Pre-elementary Schools in Medan, North Sumatera Abstract
}

\author{
by
}

\begin{abstract}
ABDUL GANI, ERLIANA MALIK MIRAZA, ISKANDAR Z. LUBIS ENDANG D. HAMID and SJARIKAT TARIGAN
\end{abstract}

(From the Department of Child Health, School of Medicine University of North Sumatera/Dr. Pirngadi Hospital, Medan)

\begin{abstract}
Anthropometric measurements bave been taken on 162 cbildren of Metbodist, Dharma Wanita USU and Aisyiab pre-elementary scbools in Medan to assess their nutritional status. This study was done cross sectionally from January to February 1990.

The nutritional status of those children were then compared among those schools with the assumption that father's income and educational level of motbers were different. By the parameters of $W / A, H / A$ and $W / H$ it showed that the nutritional status of children in the pre-elementary schools were generally quite good. Using parameters $W / A$ and $W / H$ there was a significant difference between the children in Methodist and in Aisyiab $(p<0.001)$.

University graduated mothers could be found in Dbarma Wanita USU, whereas in Methodist and Aisyiab pre-elementary schools the mothers were mostly secondary bigh school graduates.

Fatber's income above Rp. 150.000,- could be found in Metbodist pre-elementary school subsequently followed by Dharma Wanita USU pre-elementary schools, whereas in Aisyiab pre-elementary school the father's income was mostly between Rp. 100.000,and Rp. 149.999,-.

By using the Waterlow classification we found $9.88 \%$ children with acute Protein Calorie Malnutrition, whereas chronic Protein Calorie Malnutrition only $2.46 \%$.

The nutritional status of children in the tbree pre-elementary schools could be concluded as good.
\end{abstract}




\section{Introduction}

Nutritional status of infants and underfive children is an indicator of the health status of the community. The better the nutritional status of the children the better the health status of the community. Whereas, the height of school children of age 7 to 12 years is a parameter of the nutritional status and also indicates socioeconomic changes. The improvement of socio-economic levels may produce an increase in children's height $[1,2]$.

Pre-elementary school children are those between pre-schools and school age. This group is increasing in number, especially in urban areas. The nutritional status of children in this age group is not fully recognized.

The nutritional status in preelementary school children may reflect the nutritional status of infants and children 2 to 3 years later. This study is designed to assess the nutritional status of children in three pre-elementary schools in Medan and compare among the three pre-elementary schools with the assumption that father's income and mother,s education were different in those three preelementary schools.

\section{Materials and methods}

The subjects of this study were children in three pre-elementary schools in Medan, namely :

- Pre-elementary school Methodist with 82 children, of which $58 \%$ were Chinese Indonesian children. The school fee was Rp. 24.000,- per month.

- Pre-elementary school Dharma Wanita University of North Sumatera (USU) with 40 children, all of them are Indonesians. The school fee was Rp. 5000,per month.

- Pre-elementary school Aisyiah with 40 children all of them are Indonesians, with a school fee of Rp. 2500,- per month.

This study was a cross-sectional observation and conducted from January to February 1990 by using :

- Questionnaires to identify the children i.e.name, age, sex, father's income and mother's education.

- Physical examination to find signs of malnutrition.

- Anthropometric measurements i.e. weight and height.

The weight was measured using a Detecto balance with a sensitivity of 0.1 $\mathrm{kg}$ and the height was measured by a Microtoise with a sensitivity of $0.1 \mathrm{~cm}$.

- The age was obtained from the school records.

- The nutritional status was assessed using anthropometric parameters of weight/age (W/A), Height/age (H/A) and weight/height (W/H).

Classification of Protein Calorie Malnutrition was based on "Rekomendasi Lokakarya Anthropometri 1975" and the Table of the Directorate of Nutrition were used. To classify acute, chronic-acute and chronic malnutrition, the Waterlow classification was used. 
Classification of Nutritional status based on the Recommendation of Lokakarya 1975 and the Table by Directorate of Nutrition [3].

\begin{tabular}{|llll|}
\hline Category & W/A (\%) & H/A (\%) & W/H \% \\
\hline Wellnourished & $100-80$ & $100-95$ & $100-90$ \\
Moderate malnutrition & $80-60$ & $95-85$ & $90-70$ \\
Severe malnutrition & 60 & 85 & 70 \\
\hline
\end{tabular}

Standard Harvard, percentile $50^{\text {th }}$ Harvard standard is normal

Classification of Protein Calorie Malnutrition (PCM) according to Waterlow [4]

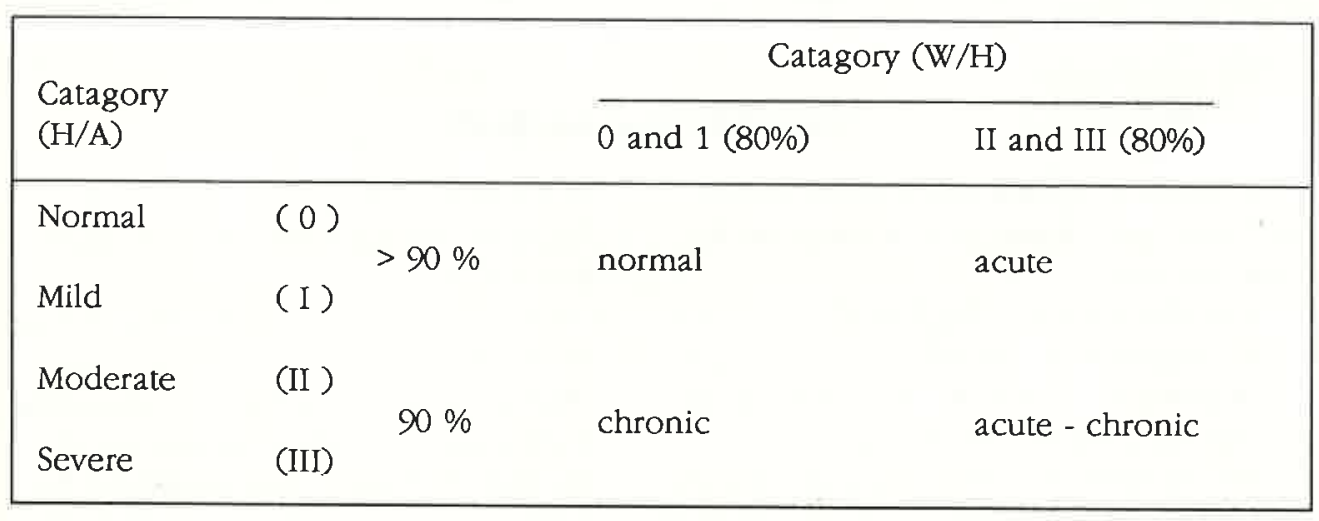

For statistical analysis the Chi Square test was used.

\section{Results}

Distribution of 162 pre-elementary school dominanty in the pre-elementary school children by age and sex (Table I). Dharma Wanita USU $(50.00 \%)$, while eleThe majority (53.7\%) of pre- mentary graduates found in methodist elementary school children was in the and in Aisyiah pre-elementary Schools age group of 5-6 years, followed by chil- namely $4.88 \%$ and $7.75 \%$, respectively dren in the age group of $4-5$ years (Table II).

$(35.80 \%)$.

The male-female ratio was $73: 89$.

Mother's education showed that secondary high school graduates appeared predominantly $(50.00 \%)$ followed by primary high school (22.20\%). Mothers who were University graduates appeared pre-
The educational levels of the mothers different significantly amongst the three pre-elementary schools ( $p<0.001)$, namely between Methodist and Dharma Waniand Aisyiah and between Dharma Wanita USU and Aisyiah $(p<0.05)$.
Table I. Distribution of Children by Age and Sex

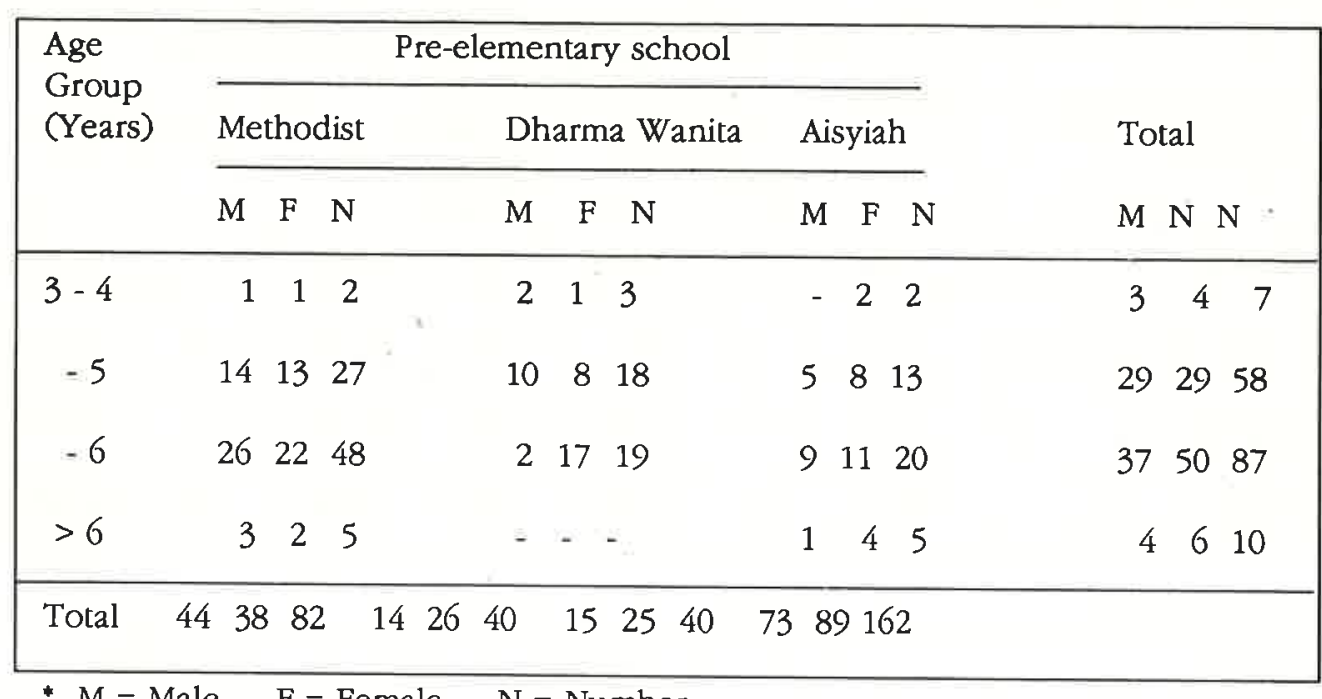

* $\mathrm{M}=$ Male $\mathrm{F}=$ Female $\mathrm{N}=$ Number

Table II. Educational Level of Motbers

\begin{tabular}{|c|c|c|c|c|c|c|c|c|c|}
\hline \multirow{2}{*}{$\begin{array}{l}\text { Pre-elementary } \\
\text { school }\end{array}$} & \multirow{2}{*}{ Number } & \multicolumn{5}{|c|}{ Educational level } & \multirow[b]{2}{*}{$\%$} & \multirow[b]{2}{*}{ UG } & \multirow[b]{2}{*}{$\%$} \\
\hline & & " ES & $\%$ & PS & $\%$ & SHS & & & \\
\hline Methodist & 82 & 4 & 4.88 & 23 & 28.03 & 42 & 51.22 & 13 & 15.85 \\
\hline Dharma Wanita & 40 & - & - & 1 & 2.50 & 19 & 47.50 & 20 & 50.00 \\
\hline Aisyiah & 40 & 7 & 17.50 & 12 & 30.00 & 20 & 50.00 & 1 & 2.50 \\
\hline \multirow[t]{2}{*}{ Total } & 162 & 11 & 6.80 & 36 & 22.20 & 81 & 50.00 & 34 & 21.66 \\
\hline & \multicolumn{3}{|c|}{$X^{2}=42.918$} & \multicolumn{2}{|c|}{$\mathrm{df}=6$} & & \multicolumn{2}{|c|}{$P<0.001$} & \\
\hline $\begin{array}{l}* \text { ES = Elementa } \\
\text { PS = Primary Hig }\end{array}$ & $\begin{array}{l}\text { ry School } \\
\text { h School }\end{array}$ & & $\begin{array}{l}\mathrm{SHS}= \\
\mathrm{UG}=\end{array}$ & $\begin{array}{l}\text { econ } \\
\text { niver }\end{array}$ & $\begin{array}{l}\text { dary Hi } \\
\text { sity Gra }\end{array}$ & $\begin{array}{l}\text { Sch } \\
\text { late }\end{array}$ & & & \\
\hline
\end{tabular}

Less than half of the fathers (45.67\%) of fathers had a moderate income, while have income of more than Rp.150.00,-. in Aisyiah most of fathers $(55.00 \%)$ had However, this relative high income ap- an income of between Rp.100.00 and peared predominantly in Methodisi Rp.149.999 (Table III).

(57.30\%). In Dharma Wanita USU, $55.00 \%$ The father's income per month in 
Table III. Income of Fathers

\begin{tabular}{|lccccccc|}
\hline & & \multicolumn{6}{c|}{ Father's income / month (Rupiah) } \\
\cline { 3 - 8 } $\begin{array}{l}\text { Pre-elementary } \\
\text { schools }\end{array}$ & Number & $\begin{array}{l}50.000 \\
99.999\end{array}$ & $\%$ & $\begin{array}{l}100.000- \\
149.999\end{array}$ & $150.000 \%$ & \\
\hline Methodist & 82 & 7 & 8.53 & 28 & 34.14 & 47 & 57.31 \\
Dharma Wanita USU & 40 & 8 & 20.00 & 10 & 25.00 & 22 & 55.00 \\
Aisyiah & 40 & 13 & 32.50 & 22 & 55.00 & 5 & 12.50 \\
\hline Total & 162 & 28 & 17.28 & 60 & 37.03 & 74 & 45.67 \\
\hline$X^{2}=27.226$ & & $\mathrm{df}=4$ & & $0<0.001$ & & \\
\hline
\end{tabular}

Table IV. Nutritional Status of Cbildren by weight/age.

\begin{tabular}{|c|c|c|c|c|c|c|c|}
\hline \multirow{3}{*}{$\begin{array}{l}\text { Pre-elementary } \\
\text { school }\end{array}$} & \multicolumn{7}{|c|}{ Nutritional Status } \\
\hline & \multirow[t]{2}{*}{ Numb } & \multicolumn{2}{|c|}{$\begin{array}{l}\text { Wellnourished } \\
\text { er }\end{array}$} & \multicolumn{2}{|c|}{ Moderate Malnutrition } & \multicolumn{2}{|c|}{ Severe Malanutriton } \\
\hline & & Number & $\%$ & Number & $\%$ & Number & $\%$ \\
\hline Methodist & 82 & 70 & 85.36 & 12 & 14.63 & - & - \\
\hline Dharma Wanita & & & & & & & \\
\hline USU & 40 & 26 & 65.00 & 14 & 35.00 & - & - \\
\hline Aisyiah & 40 & 22 & 55.00 & 17 & 42.50 & 1 & 2.50 \\
\hline Total & 162 & 118 & 72.83 & 43 & 26.54 & 1 & 0.61 \\
\hline
\end{tabular}

those three pre-elementary schools chil- children (72.83\%) were wellnourished dren significantly differed from each oth- while moderate and severe malnutrition er ( $p<0.001)$, namely between Methodist were found predominantly in Aisyiah and Aisyiah ( $\mathrm{P}<0.001$ ) also between pre-elementary school (Tabel IV).

Dharma Wanita USU and Aisyiah. Where- There was a significant difference of as between Methodist and Dharma Wani- the nutritional status among children in ta USU there was no significant differ- the three pre-elementary schools ( $p$ ence $(p>0.05)$. $<0.05$ ), i.e. between children from MethoMost of: the pre-elementary school dist and Aisyiah (Tabel IV).
Table V. Nutritional Status of Children by beight/age

\begin{tabular}{|c|c|c|c|c|c|c|c|}
\hline \multirow{3}{*}{$\begin{array}{l}\text { Pre-elementary } \\
\text { schools }\end{array}$} & \multirow{3}{*}{ Number } & \multicolumn{6}{|c|}{ Nutritional Status } \\
\hline & & \multicolumn{2}{|c|}{ Wellnourished $N$} & \multicolumn{2}{|c|}{ Moderate malnutrition } & \multicolumn{2}{|c|}{ Severe malnutrition } \\
\hline & & Number & $\%$ & Number & $\%$ & Number & $\%$ \\
\hline Methodist & 82 & 77 & 93.90 & 5 & 6.09 & - & - \\
\hline $\begin{array}{l}\text { Dharma Wanita } \\
\text { USU }\end{array}$ & 40 & 40 & 100.00 & - & - & - & - \\
\hline Aisyiah & 40 & 34 & 85.00 & 5 & 12.00 & 1 & 2.50 \\
\hline Total & 162 & 151 & 93.20 & 10 & 6.172 & 1 & 0.61 \\
\hline
\end{tabular}

Table VI. Nutritional Status of Children by weight/height.

\begin{tabular}{|c|c|c|c|c|c|c|c|}
\hline \multirow{3}{*}{$\begin{array}{l}\text { Pre- } \\
\text { elementary } \\
\text { schools }\end{array}$} & \multirow{3}{*}{ Number } & \multicolumn{6}{|c|}{ Nutritional Status } \\
\hline & & \multicolumn{2}{|c|}{ Wellnourished } & \multicolumn{2}{|c|}{ Moderate malnutrition } & \multicolumn{2}{|c|}{ Severe malnutrition } \\
\hline & & Number & $\%$ & Number & $\%$ & Number & $\%$ \\
\hline Methodist & 82 & 78 & 95.12 & 4 & 4.87 & - & - \\
\hline \multicolumn{8}{|c|}{ Dharma Wanita } \\
\hline USU & 40 & 30 & 75.00 & 10 & 25.00 & - & - \\
\hline Aisyiah & 40 & 25 & 62.50 & 14 & 35.00 & 1 & 2.50 \\
\hline Total & 162 & 133 & 82.09 & 28 & 17.28 & 1 & 1.61 \\
\hline
\end{tabular}

By using H/A parameter, 151 children (93.20\%) were wellnourished. All children in Dharma Wanita USU were wellnourished (100\%), while in Methodist 5 (6.09\%) and in Aisyiah 5 (12.00\%) had moderate malnutrition ( $p>0.05$ ) (Tebel V).

By using $\mathrm{W} / \mathrm{H}$ parameter, 133 childrèn (82.09\%) were wellnourished. In Metho-

dist, Dharma Wanita USU and Aisyiah moderate malnutrition was found in $4.87 \%, 25.00 \%$ and $35.00 \%$, respectively. Whereas in Aisyiah, $2.50 \%$ showed severe malnutrition (Tabel VI)

Statistically, the nutritional status in children of the three pre-elementary schools showed significant differences $(\mathrm{p}<0.001)$. 
Table VII. Waterlow Classifications

\begin{tabular}{|lcccccccccc|}
\hline $\begin{array}{l}\text { Pre- } \\
\text { elementary } \\
\text { schools }\end{array}$ & \multicolumn{2}{c}{$\begin{array}{c}\text { Number } \\
\text { Number }\end{array}$} & & Numourished & Acute PCM & Chronic PCM & Acute 8 Chronic PCM \\
\hline Methodist & 82 & 78 & 91.12 & 1 & 1.21 & 1 & 1.21 & 2 & 2.43 \\
$\begin{array}{l}\text { Dharma Wanita } \\
\text { USU }\end{array}$ & 40 & 30 & 75.00 & 8 & 20.00 & - & - & 2 & 5.00 \\
Aisyiah & 40 & 25 & 62.50 & 7 & 17.50 & 3 & 7.50 & 5 & 12.50 \\
\hline Total & 162 & 133 & 82.10 & 16 & 9.88 & 4 & 2.46 & 9 & 5.60 \\
\hline
\end{tabular}

$\mathrm{PCM}=$ Protein calorie malnutrition

By the Waterlow classification, 133 in Aisyiah $3(7.50 \%)$ were in chronic (82.10\%) pre-elementary school children PCM, and $5(12.50 \%)$ were in acutewere wellnourished. In Dharma Wanita chronic PCM (Tabel VII).

USU 8 (20.00\%) had acute PCM, whereas

\section{Discussion}

Generally by using the parameters W/A, found by Puslitbang Gizi Bogor in Indo$\mathrm{H} / \mathrm{A}$ and $\mathrm{W} / \mathrm{H}$, children in the three pre- nesia (rural and urban areas) that higher elementary schools were wellnourished levels of social economy may produce although by the W/H parameter moder- lower rates of PCM (5).

ate malnutrition still appeared in 28 In Dharma Wanita USU pre$(17.28 \%)$ and severe malnutrition in 1 elementary school, where $50 \%$ of the $(0.61 \%)$.

Based on W/A and W/H criteria a significant difference of the nutritional status was found between the children in Methodist and Aisyiah pre-elementary schools, while no significant difference was found between Methodist and Dharma Wanita USU pre-elementary schools. The significant difference between Methodist and Aisyiah pre-elementary schools may be associated with the father's income. Most of the father's income in pre-elementary school Methodist was Rp.150.000,-/month (57.31\%), while in Aisyiah pre-elementary school it was Rp. 100.000 to Rp.149.999 $(55.00 \%)$. This finding is similar with that mothers were University graduates, 25\%

children still suffered from moderate malnutrition. Whereas in Methodist preelementary school, mothers were senior high school graduates and most of the children were wellnourished. The mother's education level seemed to have less important influence on the children's nutritional status. Similar findings were found by the study of the Puslitbang Gizi Bogor in some cities of Sumatera where the level of educations of the mothers did not affect the degree of PCM of underfive children (5). moderate malnutrition, and $0.61 \%$ severe.
By using H/A, $6.17 \%$ of children had
This condition indicated malnutrition in by the on going improvement of sociothe past. No significant difference was economic level.

found in the three pre-elementary Using the Waterlow classification we schools although the father's income in could differentiate acute PCM from chronMethodist pre-elementary school was ic PCM. Presently acute PCM and acutehigher. This limited study had failed to chronic PCM in the three pre-elementary follow the increase in height in the future schools need prompt treatment.

\section{Conclusion}

1. Using the parameters of W/A, H/A and $\mathrm{W} / \mathrm{H}$, children of the three preelementary schools in Medan were generally wellnourished.

2.Using the parameters of $\mathrm{W} / \mathrm{A}, \mathrm{W} / \mathrm{H}$ there were significant differences of nutritional status between Methodist and Aisyiah pre-elementary schools ( $P$ $<0.001$ ).

3. University graduate mothers could be found in Dharma Wanita USU preelementary school, whereas in Methodist and Aisyiah pre-elementary schools the mothers were mostly secondary high school graduates.

4. Father's income above Rp.150.000,,were mostly found in Methodist preelementary school subsequently followed by Dharma Wanita USU preelementary school, whereas in Aisyiah pre-elementary school the father's income was mostly between Rp.100.000,and Rp.149.999,-.

5. By the classification of Waterlow, $9.88 \%$ children had PCM, and the chronic type was found only in $2.46 \%$ of those children.

\section{REFERENCES}

1. Abuanain D. Pengukuran tinggi badan anak 3. Jahari AB. Antropometri sebagai indikator baru masuk sekolah dasar sebagai metode identilkasi dan penilaian keachan gizi pen duduk, pengalaman di tiga Propinsi. Gizi Indonesia $1988 ; 13: 40-50$.

2. Enoch M. Tinggi badan pada umur tertentu sebagai indikator gizi dan kesehatan masyarakat. Medika $1988 ; 7: 672-7$. 30.

4 Waterlow IC Nutritional Effects on Growth. Clin Nutr Young child 1985: 59 - 65.

5. PUSLITBANG Gizi. Permasalahan gizi di Indonesia dewasa ini. Gizi Indonesia 1988 ; $13: 49-81$. 